УДК 636.7.09: 616.995.42-071

(C) 2016

Прус М. П., доктор ветеринарних наук, Шайдюк М. В., аспірант

(науковий керівник - доктор ветеринарних наук М. П. Прус)

Національний університет біоресурсів і природокористування України

\title{
МЕТОДИ ДІАГНОСТИКИ ЕРЛІХІОЗУ СОБАК
}

\section{Рецензент - доктор ветеринарних наук Н. М. Сорока}

Відмічено, щзо питання діагностики ерліхіозу собак нині стоїть досить гостро. Проаналізовано основні методи діагностики та їх ефективність на різних етапах перебігу захворювання. Визначення перспективності діагностики ерліхіозу методом безпосереднього мікроскопічного дослідження мазків периферичної крові. Проведено порівняння різних методів фарбування мазків периферичної крові під час діагностики бабезіозу та ерліхіозу. Відмічено, щзо виявити E. canis y крові достатньо важко $і$ можливі хибні результати. Мікроскопія мазків крові (на відміну від серологічної діагностики) дає можливість діагностувати ерліхіоз на ранній стадї захворювання.

Ключові слова: ерліхіоз, мікроскопія, морула, діагностика, імуноферментний аналіз.

Постановка проблеми. Ерліхіози - об'єднані в одну групу трансмісивні захворювання людей $i$ ссавців, викликані бактеріями роду Ehrlichia i характеризуються розвитком синдрому загальної інтоксикації і специфічним ураженням лейкоцитів, значно рідше - макрофагів і ендотеліальних клітин $[1,3,6,10]$.

Процес систематизації ерліхіозів триває і нині. Так, Anaplasma phagocytophilum - нова назва виду, присвоєна після проведеного філогенетичного аналізу представників родини Anaplasmataceae, що об'єднує в собі мікроорганізми, раніше відомі як Ehrlichia phagocytophila, Ehrlichia equi. Ehrlichia platus перейменована на Anaplasma platus, Ehrlichia ristici тепер називається Neorickettsia ristici [4].

За сучасною систематикою рід Ehrlichia включає види Е. canis, E. chaffeensis, E. ewingii, E. muris i E. ruminantium [2].

Ерліхіоз собак, що викликається збудником Ehrlichia canis, був уперше описаний в Алжирі в 1935 році. [8]. Згодом дане захворювання було виявлене і в інших країнах Африки, Азії, Близького Сходу та Європи.

Інкубаційний період за ерліхіозу становить 1-3 тижні. Виділяють гостру, субклінічну і хронічну фази захворювання. В гострій фазі хвороби спостерігаються такі клінічні ознаки, як гіпертермія, апатія, анорексія, лімфаденопатія, що зникають через
20-30 діб, і наступає довгий період субклінічної фази $[3,6,7,10]$. Субклінічна фаза триває різний період і пов'язана з вірулентністю збудника. Тромбоцитопенія, лейкопенія та анемія зберігаються за тимчасової відсутності клінічних ознак. Хронічна фаза характеризується крововиливами, носовою кровотечею, периферичними набряками, виснаженням $[3,6,7,10]$. Під час лабораторних досліджень відзначають тромбоцитопенію, лейкопенію, анемію і гіпергамаглобулінемію [3, 6, 9]. Супутні хвороби (бабезіоз та гемобартонельоз) можуть загострювати клінічні ознаки [10].

Питання діагностики ерліхіозу собак нині стоїть досить гостро. Специфічна діагностика моноцитарного ерліхіозу включає методи прямого виявлення збудника і серологічну діагностику. Прямі методи направлені на виявлення збудника в моноцитах під час мікроскопії мазка периферичної крові і ПЛРдіагностики. Непрямі (серологічні) методи дають змогу виявляти антитіла (імуноглобуліни класів $\mathrm{G}$ i М) до ерліхій у сироватці крові хворих тварин.

Аналіз останніх досліджень і публікацій, у яких започатковано розв'язання проблеми. Метод безпосереднього мікроскопічного дослідження мазків периферичної крові, пофарбованих за методом Романовського-Гімзи, є простим і недорогим. Морфологічно всі види ерліхій $є$ невеликими плеоморфними кокоподібними або овоїдними утвореннями, що мають темно-синій або пурпурний відтінок. Знаходяться у вигляді характерних включень в цитоплазмі нейтрофілів або моноцитів. Формування видимої морули відбувається на 5-7-му добу після проникнення збудника в моноцит. Даний метод дослідження найбільш ефективний за гострого перебігу захворювання.

Проте цей метод може бути малоефективним за низького рівня збудника в моноцитах і часто поширені хибно-негативні результати. Також цей метод вимагає досвіду і специфічних навичок у персоналу.

Позитивний результат мікроскопії мазка крові дає підстави для постановки остаточного діагнозу i можна відмовитися від проведення інших додаткових досліджень $[5,10]$. Другий прямий метод - 


\section{ВЕТЕРИНАРНА МЕДИЦИНА}

ПЛР-діагностика. Для ПЛР-дослідження придатні як самі кліщі, яких знаходять у природі або знімають $з$ ураженої тварини, так і кров.

Кров беруть у пробірки з ЕДТА на піку температури, оскільки саме в цей період концентрація збудника в крові максимальна [5]. Проте діагностика за допомогою полімеразної ланцюгової реакції в Україні частіше використовується під час проведення наукових досліджень і нині не $\epsilon$ широко поширеним методом в практичній ветеринарії.

Всі збудники ерліхіозу викликають специфічну відповідь гуморального імунітету. Ця відповідь входить в основу серологічної діагностики хвороби. У тварин з гострою формою захворювання спостерігається виражене зростання титрів антитіл, а за хронічного перебігу - їх стабільно високий рівень.

Серологічна відповідь виникає в організмі кожної тварини, яка піддавалася дії Е. canis, незалежно від того чи виникало захворювання. Тому лише одна серологія без наявності клінічних ознак не дає достатньо інформації для діагностики хвороби.

Серологічні методи нині представлені реакцією непрямої імунофлуоресценції, методом імуноблотинга і імуноферментним аналізом (IФА) $[3,5,6$, 10], за допомогою яких виявляються специфічні імуноглобуліни до збудника моноцитарного ерліхіозу класів G і М. Для точної діагностики потрібна динаміка титрів специфічних антитіл до антигенів збудника (сероконверсія).

Сероконверсія - це поява або підвищення титру антитіл до антигена, який потрапляе в організм в результаті інфікування або імунізації. Поняття «сероконверсія» часто використовується в діагностиці і епідеміології як ознака інфекції або критерій ефективності вакцинації. У обох випадках, для доказу наявності сероконверсії, потрібне дослідження парних (серійних) зразків сироватки крові, перший з яких був узятий до початку або на самому початку антигенної дії, а подальші - в період очікуваного максимуму імунної відповіді. Встановлення сероконверсії зі зростанням титру специфічних антитіл в сироватці крові $є$ ознакою розвитку захворювання.

Для встановлення сероконверсії за ерліхіозу досліджують проби сироватки крові, узяті від тварини 3 інтервалом в 7-14 діб. Відсутність високого титру антитіл або сероконверсії не можна вважати доказом відсутності інвазування Е. canis, оскільки специфічні антитіла при ній досягають рівня, що виявляється серологічними тестами, не раніше 3-х тижнів після зараження.

Імуноглобуліни класу М (ранні антитіла, IgM) починають з'являтися після 9-ї доби хвороби і до- сягають максимуму на 10-12-ту добу, потім їх концентрація поступово зменшується. Такий пізній розвиток імунної відповіді дає змогу поставити діагноз лише постфактум і не може допомогти лікареві у своєчасному призначенні лікування. Проте таке дослідження потрібне для епізоотичного спостереження і пізньої верифікації діагнозу. Імуноглобуліни класу $\mathrm{G}(\operatorname{IgG})$ з'являються вже 3 перших днів захворювання i ïх титр неухильно зростає, досягаючи максимуму на 21-28-му добу, що також не може бути використано для ранньої діагностики і визначення тактики лікування, оскільки антитіла можуть виявлятися після перенесеного захворювання довічно.

Таким чином, серологічні методи частіше використовуються для верифікації первинного діагнозу, діагностики субклінічної стадії захворювання і епізоотичного нагляду за кліщовими інвазіями [5].

Мета досліджень: визначення перспективності діагностики ерліхіозу методом безпосереднього мікроскопічного дослідження мазків периферичної крові, порівняння різних методів фарбування мазків.

Матеріал і методи досліджень. Наші дослідження проведені в КП «Київська міська лікарня ветеринарної медицини» (м. Київ, вул. Ярославська, 13a). Діагноз на трансмісивні кровопаразитарні хвороби встановлювали шляхом аналізу анамнезу, детального клінічного обстеження тварини, а також його підтверджували мікроскопією мазків крові, пофарбованих за Паппенгеймом та за методикою з використанням набору для швидкого фарбування мазків крові Лейкодіф 200. Серологічна діагностика методом ІФА проводилася в лабораторії «Бальд» (м. Київ) через 1 місяць 3 моменту інвазування.

Результати досліджень. Для даного дослідження була сформована група тварин, що піддавалися нападу кліщів та надійшли до КП «Київська міська лікарня ветеринарної медицини» для проведення діагностики та лікування.

Типовими симптомами були: підвищення температури тіла до $39,5-41,0{ }^{\circ} \mathrm{C}$, апатія, анорексія. У деяких випадках спостерігалась блідість або жовтяничність слизових оболонок, гемоглобінурія.

Для постановки діагнозу проводилася мікроскопія мазків периферичної крові, пофарбованих за Паппенгеймом (фіксацію мазків проводили в барвнику по Май-Грюнвальду 2 хвилини і потім фарбували 20 хвилин барвником за РомановськимГімзою) та за методикою з використанням набору для швидкого фарбування мазків крові Лейкодіф 200. 
Результати мікроскопії мазків крові, серологічної діагностики та клінічні ознаки собак, хворих на ерліхіоз

\begin{tabular}{|c|c|c|c|}
\hline Собака & $\begin{array}{c}\text { Результати мікроскопії } \\
\text { мазка крові на наяв- } \\
\text { ність морул ерліхій }\end{array}$ & Клінічні ознаки ерліхіозу & $\begin{array}{c}\text { Результати серологіч- } \\
\text { ного дослідження } \\
\text { (через 1 місяць) }\end{array}$ \\
\hline $\begin{array}{c}\text { Альба, спаніель, 10 р., } \\
\text { самка }\end{array}$ & Позитивний & Гіпертермія & Низький титр антитіл \\
\hline Віник, метис, 3 р., самець & Позитивний & Гіпертермія & Низький титр антитіл \\
\hline Мотя, метис, 3 р., самка & Позитивний & Носова кровотеча & Низький титр антитіл \\
\hline Малиш, метис, 2 р., самець & Позитивний & Безсимптомно & Низький титр антитіл \\
\hline $\begin{array}{c}\text { Хард, вельштер'єр, 3 р., } \\
\text { самець }\end{array}$ & Позитивний & Безсимптомно & Середній титр антитіл \\
\hline
\end{tabular}

У тварин був виявлений збудник Babesia canis. Також у даних тварин в моноцитах виявлені морули ерліхій.

Суттєвої різниці під час використання різних методик фарбування мазків крові для постановки діагнозу не виявлено. Проте ми надаємо перевагу методиці 3 використанням набору для швидкого фарбування мазків крові Лейкодіф 200 , оскільки фарбування мазків технічно простіше та швидше (3-5 хвилин).

Після проведення специфічної терапії бабезіозу препаратом «Азидин-вет» (виробництва компанії «Бровафарма») через 2 доби у 2-х тварин знову відмічалося підвищення температури тіла до $40{ }^{\circ} \mathrm{C}$, у 3-ї спостерігалась носова кровотеча. У 4-ї і 5-ї собаки клінічних ознак ерліхіозу не виявляли.

Після проведення специфічної терапії бабезіозу препаратом «Азидин-вет» виявити морули ерліхій не вдавалося.

Можливість отримання хибного результату під час мікроскопії мазків периферичної крові досить висока. Інтерпретація артефактів, як морули ерліхій, часто призводить до хибнопозитивних результатів. Тому цей метод вимагає досвіду і специфічних навичок у діагноста.

Враховуючи вищезазначене, ми для підтвердження діагнозу «ерліхіоз» (який був поставлений

\section{БІБЛІОГРАФІЯ}

1. Карташов С. Н. Клинико-лабораторные особенности эрлихиоза у собак [текст] / С. Н. Карташов, А. Г. Клочников, А. М. Ермаков // Ветеринария Кубани. - 2010. - №4. - С. 24-26.

2. Эрлихиоз: современное состояние проблемы [текст] / [Козько В. Н., Юрко Е. В., Похил С. И., Тимченко О. М.] // Клиническая инфектология и паразитология. - 2012. - №3-4. - С. 77- 87.

3. Ниманд Х. Г. Болезни собак. Практическое руководство для ветеринарных врачей (организация ветеринарной клиники, обследование, диаг- методом мікроскопії мазків крові) через 1 місяць 3 моменту інвазії, провели серологічну діагностику методом ІФА в лабораторії «Бальд» (м. Київ). У сироватці крові собак були виявлені антитіла до Ehrlichia canis (у середньому титрі - в 1-ї собаки, в низькому - у 4-ї). Також було проведено мікроскопію мазків крові даних тварин. Морули ерліхій у моноцитах виявлені не були.

Результати мікроскопії мазків крові, серологічної діагностики та клінічні ознаки собак, хворих на ерліхіоз, наведені у таблиці.

\section{Висновки:}

1. Діагностувати ерліхіоз мікроскопією мазків крові можливо лише в гострий період і лише до проведення специфічної терапії бабезіозу.

2. Виявити E. canis у крові досить важко і часто поширені хибні результати.

3. Мікроскопія мазків крові (на відміну від серологічної діагностики) дає можливість діагностувати ерліхіоз на ранній стадії захворювання.

4. Серологічні методи частіше використовуються для верифікації первинного діагнозу, діагностики безсимптомної стадії захворювання i епізоотичного нагляду за кліщовими інвазіями.

5. Суттєвої різниці під час використання різних методик фарбування мазків крові 3 метою встановлення збудників ерліхіозу не виявлено.

ностика заболеваний, лечение) [текст] / Х. Г. Ниманд, П. Ф. Сутер. - М. : Аквариум-Принт, 2008. $-816 \mathrm{c}$.

4. Рap B. A. Изучение генетического разнообразия анаплазм и эрлихий в паразитарных системах юга Западной Сибири и Урала [текст] / В. А. Рар, Н. Н. Ливанова, В. В. Панов // Бюллетень сибирской медицины. - 2006. - Прилож. 1. C. $116-121$.

5. Селиванов E. B. Моноцитарный эрлихиоз человека [текст] / Е. В. Селиванов // Вестник 


\section{ВЕТЕРИНАРНА МЕДИЦИНА}

«лаборатории ДНК-диагностики». - 2012. №1(14). - С. 26-29.

6. Цачев И. Ц. Моноцитарный эрлихиоз у собак [текст] / И. Ц. Цачев, И. Д. Димов // Мир ветеринарии. - 2011. - №5(9). - С. 4-8.

7. Buhles $W$. C. Tropical canine pancytopenia: clinical, hematologic, and serologic response of dogs to Ehrlichia canis infection, tetracycline therapy, and challenge inoculation [техt] / W. C. Buhles, D. L. Huxsoll, M. Ristic // J. Infect. Dis. - 1974. Vol. 130. - P. 357-367.
8. Donatien A. Existence in Algerie d'une Rickettsia du chien [Text] / A. Donatien, F. Lestoquard // Bull. Soc. Pathol. Exot. - 1935. - Vol. 28. - P. 418419.

9. Kuehn N. F. Clinical and hematologic findings in canine ehrlichiosis / N. F. Kuehn, S. D. Gaunt // J. Am. Vet. Med. Assoc. - 1985. - Vol. 186. P. 355-358.

10. Rikihisa $Y$. The tribe Ehrlichieae and ehrlichial diseases [техt] / Y. Rikihisa // Clin. Microbiol. Reviews. - 1991. - Vol. 4. - P. 286-308. 